\title{
Studi Konversi Pati Ubi Kayu (Cassava Starch) menjadi Glukosa secara Enzimatik
}

\author{
Gita Indah Budiarti ${ }^{1 *}$, Siswo Sumardiono ${ }^{2}$ Kusmiyati $^{3}$ \\ 1*Program Studi Teknik Kimia FTI UAD, Kampus III, J1. Supomo, Janturan, Warungboto, Yogyakarta \\ 55164 \\ ${ }^{1}$ Program Magister Teknik Kimia, Fakultas Teknik, Universitas Diponegoro \\ Semarang, Jawa Tengah, Indonesia \\ ${ }^{2}$ Jurusan Teknik Kimia, Fakultas Teknik, Universitas Muhammadiyah Surakarta \\ *email: gita.indah@che.uad.ac.id
}

\begin{abstract}
Cassava starch has potential as raw material for production glucose and fructose in Indonesia. Glucose of cassava starch can be used as substitute of cane sugar and synthetic sweetener. Glucose of starch production process includes acid hydrolysis and enzymatic hydrolysis. Enzymatic hydrolysis is usually used because non-corrosive, low reaction temperatures and no contaminate product of hydrolysis. Therefore, the purpose of this paper is to provide existing knowledge of steps process, factors influencing, kind of enzyme and sugar product from enzymatic hydrolisis of cassava starch.
\end{abstract}

Keywords: Cassava Starch, Glucose, Hydrolisis Enzymatic

\section{Pendahuluan}

Ubi kayu merupakan tanaman yang sangat penting di daerah tropis seperti di Indonesia. Di Indonesia produksi ubi kayu tahun 2015 sebesar 3,6 juta ton. Khuusnya di Jawa Tengah produksi ubi kayu tahun 2015 mencapai 21,8 juta ton [1]. Di Indonesia ubi kayu dikenal sebagai bahan pangan pengganti nasi. Ubi kayu juga dapat memiliki nilai lebih selain sebagai bahan makanan. Pati yang dihasilkan ubi kayu banyak dimanfaatkan di bidang pangan, industri kertas, industri tekstil dan di industri kimia sebagai penghasil bioethanol [2-4].

Pati ubi kayu merupakan sumber pati umbi-umbian pertama di Asia. Sumber pati di Asia 60\% berupa umbi-umbian seperti ubi kayu 29\%, ubi jalar $26 \%$, dan kentang 5\%. Di negara berkembang seperti Indonesia hasil panen dari umbi-umbian lebih dominan sebagai penghasil pati dibandingkan dengan hasil panen dari biji-bijian. Kelebihan pati ubi kayu dibandingkan pati yang sering digunakan yaitu pati jagung adalah nilai konversi glukosa pati ubi kayu lebih besar dari pati jagung yaitu sebesar 93,56 \% , sedangkan pati jagung hanya $91,8 \%$ [5-8 ].

Gula merupakan kebutuhan yang krusial bagi masyarakat Indonesia terutama untuk konsumsi dan pengolahan makanan. Kebutuhan gula di Indonesia masih didominasi oleh gula pasir (sukrosa). Kebutuhan ekspor gula sampai bulan Mei 2016 mencapai 281 ton/ tahun. Kebutuhan ekspor dan dalam negeri tersebut masih diperoleh dari impor sebesar 3,68 juta ton/ tahun [1]. Kebutuhan gula yang besar tersebut, menyebabkan harus mencari pemanis alternatif pengganti gula sukrosa. Pemanis alternatif dibedakan menjadi dua, yaitu pemanis alami dan buatan. Pemanis buatan dari bahan kimia antara lain siklamat dan aspartam. Namun, dewasa ini pemanis buatan kurang diminati karena dapat menimbulkan penyakit kanker. Pemanis alami antara lain glukosa dan fruktosa dari berbagai tanaman yang menghasilkan polisakarida salah satunya adalah pati ubi kayu [68]. Melimpahnya produksi pati ubi kayu di Indonesia membuktikan bahwa ubi kayu berpotensi sebagai bahan baku glukosa dan fruktosa untuk memenuhi kebutuhan masyarakat Indonesia $[9,10]$.

Glukosa dari pati dapat diproduksi dengan cara hidrolisis asam maupun hidrolisis enzimatik. Untuk hidrolisis asam, katalis asam yang digunakan adalah asam kuat $\mathrm{HCl}$ atau $\mathrm{H}_{2} \mathrm{SO}_{4}$ [11-13]. Hidrolisis enzimatik menggunakan enzim $\alpha$-amilase pada proses likuifikasi, dilanjutkan enzim glucoidase pada tahap sakarifisasi [3,14-16]. Pembuatan glukosa dari pati ubi kayu telah banyak dilakukan antara lain, Silva et al. [17] meneliti tentang teknologi untuk membuat glukosa dan fruktosa dari Brazillian cassava starch menggunakan enzim yang diproduksi oleh mikroorganisme tanah yang diisolasi dari tanah Brazillian Cerrado. Ulibarri dan Hall [18] meneliti tentang proses sakarifikasi tepung pati singkong menggunakan Hollow-Fiber Membrane Reactor. Dalam penelitian tersebut berbagai metode digunakan untuk memperoleh konversi glukosa yang maksimal. Dewasa ini metode hidrolisis enzimatik lebih dipilih, karena yield yang dihasilkan lebih baik 
dibandingkan hidrolisis asam. Produk hidrolisis enzimatik lebih aman untuk dikonsumsi dibandingkan dengan hirolisis asam. Artikel ini membahas tentang tahapan proses, faktor-faktor yang mempengaruhi, enzim yang digunakan dan gula yang dihasilkan dari hidrolisis enzimatik pati ubi kayu.

\section{Tinjauan Pustaka}

\section{Karakteristik Ubi Kayu}

Ubi kayu adalah pohon tahunan yang hidup di daerah tropis dan subtropis. Ubi kayu (Manihot Utilissima Phol) merupakan jenis tanaman berkayu, beruas, panjang dan tinggi pohonnya bisa mencapai sekitar 3 meter atau lebih. Akar dari ubi kayu bisa mencapai 20-80 cm dan diameternya bisa mencapai 5-10 cm. Ukuran diameter dan akar tergantung pada jenis ubi kayu [19].

Ubi kayu mengandung karsiogenik glukosida linamarin dan lotaustralin yang akan menghasilkan asam sianida (HCN) apabila terjadi kerusakan pada tanaman. Ubi kayu dapat digolongkan menjadi dua yaitu ubi kayu pahit (Manihot palmate) dan ubi kayu manis (Manihot aipi), ubi kayu manis mengandung HCN kurang dari $50 \mathrm{mg} / \mathrm{kg}$ sehingga tidak beracun. Ubi kayu mengalami kerusakan dalam waktu 48 jam, yang diawali dengan perubahan secara enzimatik dalam umbi tersebut lalu terjadi pembusukan. Tanpa adanya perlakuan pascapanen yang tepat ubi kayu tidak dapat disimpan lebih dari dua hari. Komponen pati dari ubi kayu dapat dilihat pada Tabel 1 [20].

Tabel 1. Komposisi Pati pada Tanaman Ubi Kayu

\begin{tabular}{ccc}
\hline No. & Komposisi & Persen Berat (\%) \\
\hline 1 & Karbohidrat & 87,87 \\
2 & Lemak & 0,51 \\
3 & Protein & 1,60 \\
4 & Air & 7,80 \\
5 & Abu & 2,22 \\
\hline
\end{tabular}

\section{Struktur Pati Ubi Kayu}

Pati tersusun dari dua komponen utama yaitu amilosa dan amilopektin. Amilosa tersususun atas ikatan glukosa 1-4 glukosa. Amilopektin tersusun atas ikatan 1-4 glukosida dan 1-6 glukosida [19,21,22]. Pati ubi kayu mempunyai kemampuan untuk membentuk gel melalui proses pemanasan pada suhu $90{ }^{0} \mathrm{C}$ atau lebih sebagai akibat dari pecahnya struktur amilosa dan amilopektin. Pemecahan tersebut menyebabkan terjadinya perubahan lebih lanjut seperti peningkatan molekul air sehingga terjadi penggelembungan molekul, pelelehan kristal dan terjadi peningkatan viskositas [23].

Struktur granula pati ubi kayu adalah semi-crystalline yang terdiri dari ikatan amilopektin dengan berat molekul sebesar $0,7.10^{8}$ dan amilosa sebesar $1,03.10^{6}$. Gambar 2 adalah gambar scanning electron microscopy (SEM) dari granula pati ubi kayu pada sampel WTCS (Wild Type Cassava Starch) atau pati singkong biasa dan AMFCS (Amylose Free Cassava Starch) yaitu pati singkong yang bebas amilosa [24]. Karakteristik pati pada ubi kayu seperti komposisi kimia, morfologi granula pati dan sifat gelatinisasi dipengaruhi oleh komponen yang berada pada akar ubi kayu [25,26].

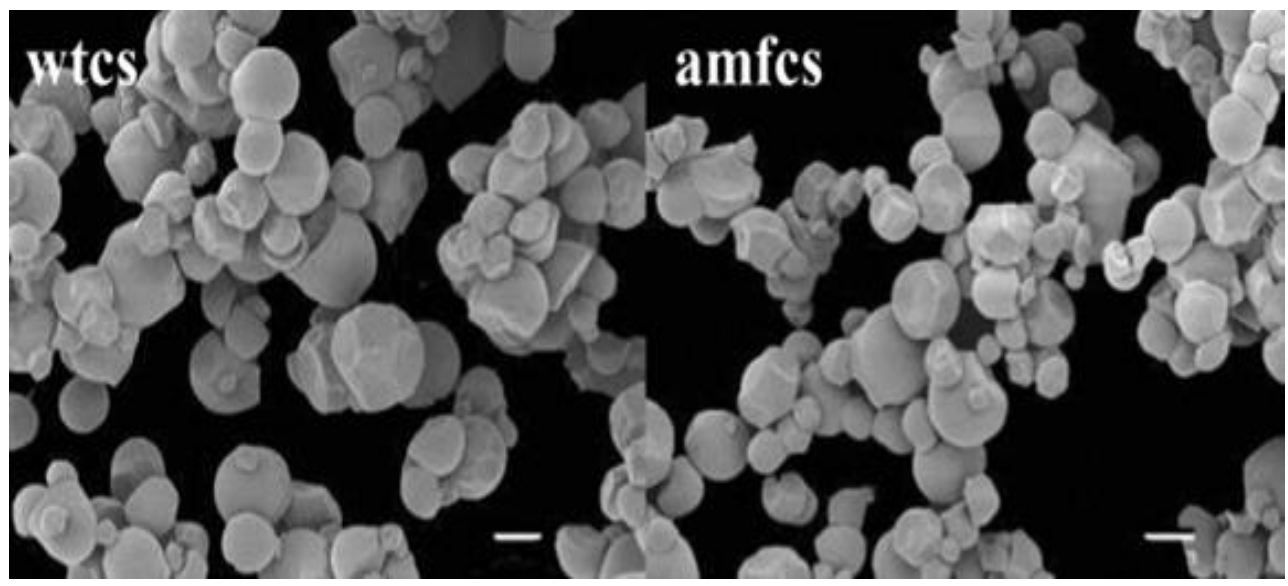

Gambar 1. Scanning Electron Microscopy (SEM) dari Granula Pati Ubi Kayu 


\section{Pembuatan Glukosa dan Fruktosa dengan Hidrolisis Pati}

\section{Hidrolisis Asam}

Hidrolisis pati dengan katalis asam pertama kali ditemukan oleh Kirschoff dari pemanasan pati mentah dalam $\mathrm{H}_{2} \mathrm{SO}_{4}$. Kemudian hidrolisis pati menggunakan $\mathrm{HCl}$ pada temperatur $130-170{ }^{0} \mathrm{C}$ dengan proses selanjutnya yaitu netralisasi. Faktor yang menentukan pada hidrolisis asam adalah temperatur, konsentrasi asam dan waktu hidrolisis [27]. Wojciechowski, et al [16] melakukan hidrolisis asam pati ubi kayu menggunakan katalis $\mathrm{HCl}$ konsentrasi $1 \%$ selama 10 menit dengan suhu $120{ }^{\circ} \mathrm{C}$, konversi glukosa yang diperoleh sebesar 94,5\%. Yoonan dan Kongkiattikajorn [13] melakukan penelitian hidrolisis asam menggunakan katalis $\mathrm{HCl}$ dengan konsentrasi $0,1 \mathrm{M}$, konsentrasi pati 1,5\% w/v selama 90 menit di bawah suhu $135{ }^{\circ} \mathrm{C}$. Kondisi proses tersebut memperoleh konversi sebesar 66,28\%.

Proses hidrolisis dengan asam suhu yang digunakan tinggi yaitu antara $140-160{ }^{\circ} \mathrm{C}$. Kelemahan dari hidrolisis asam antara lain peralatan yang digunakan harus tahan korosi karena katalis yang digunakan adalah asam kuat, menghasilkan sakarida dengan spektra tertentu saja karena katalis asam menghidrolisis secara acak, menyebabkan terjadinya degradasi karbohidrat maupun rekombinasi produk degradasi yang dapat mempengaruhi rasa, warna dan dapat menimbulkan masalah teknis [28].

\section{Hidrolisis Enzimatis}

Dewasa ini metode konvensional hidrolisis asam sudah diganti dengan hidrolisis enzimatik. Hidrolisis enzimatik adalah proses hidrolisis yang dilakukan menggunakan katalis berupa enzim. Enzim tersebut dapat berasal dari bakteri atau fungi. Bakteri atau fungi yang sering digunakan adalah Bacillus dan Thermomyces lanuginosus [29]. Enzim yang digunakan berupa enzim $\alpha$-amilase dan enzim glukoamilase (glukosidase). Enzim $\alpha$-amilase digunakan pada tahap likuifikasi sedangkan enzim glukosidase digunakan pada tahap sakarifikasi. Hidrolisis enzimatik memberikan banyak kelebihan dibandingkan dengan hidrolisis asam. Hidrolisis enzimatik mencegah terjadinya berbagai efek samping karena sifat enzim yang sangat spesifik, sehingga dapat mempertahankan warna dan rasa dari glukosa yang dihasilkan [28].

Keuntungan yang diperoleh dari hirolisis enzimatik adalah yield yang dihasilkan tinggi. Degradasi pati dengan enzim memperoleh perhatian besar dari industri enzim karena pentingnya pati, gula dan produk lainnya di era bioteknologi modern saat ini [30]. Namun biaya operasional hidrolisis enzimatik lebih tinggi karena menggunakan katalis berupa enzim. Hidrolisis enzimatik sangat penting untuk memproduksi sirup glukosa dari pati karena dapat memisahkan ikatan pada pati secara spesifik sesuai dengan karakter sifat kimia dan sifat fisika dari pati tersebut [31]. Faktor yang dapat mempengaruhi hidrolisis enzimatik antara lain :

a. Konsentrasi Pati

Konsentrasi pati yang digunakan biasanya sekitar 30-40\% pati kering. Pada konsentrasi enzim yang tetap, konsentrasi pati yang rendah, kecepatan pati linier terhadap substrat dan reaksinya mengikuti reaksi orde satu. Konsentrasi substrat yang semakin tinggi, maka kecepatan reaksi akan semakin besar dan akan mendekati konstan. Pada keadaan ini kecepatan reaksi mengikuti persamaan kecepatan reaksi orde nol [32].

\section{b. Konsentrasi enzim}

Kecepatan reaksi linier dengan konsentrasi enzim. Pada umumnya hal ini terjadi pada substrat yang dikonversi enzim belum mencapai 10-20\% substrat [33]. Konsentrasi enzim adalah salah satu yang mempengaruhi yield glukosa dan fruktosa. Enzim memberi kontribusi $23-40 \%$ dari total biaya proses produksi, dengan kata lain jumlah enzim mempunyai dampak yang signifikan bagi kelangsungan ekonomi pada proses tersebut [34].

c. Waktu hidrolisis

Waktu yang diperlukan untuk hidrolisis tergantung pada jumlah enzim yang digunakan. Untuk enzim glukoamilase 1,25-1,5 liter/ ton pati memerlukan waktu sekitar 48-72 jam. Pada waktu inkubasi 36 jam yield gula pereduksi dari cassava starch sebesar $68,9 \mathrm{mg} / \mathrm{g}$ lalu setelah 72 jam yield naik menjadi $200,1 \mathrm{mg} / \mathrm{g}$ Jika reaksi lebih lama dari waktu tersebut maka DE pada produk akan berkurang. Hal ini disebabkan oleh adanya resintesis maltosa dan isommaltosa dari glukosa [35].

d. $\mathrm{pH}$

Setiap enzim mempunyai $\mathrm{pH}$ optimal untuk setiap aktifitasnya. $\mathrm{pH}$ yang tidak sesuai akan menyebabkan penurunan aktifitas enzim. Untuk proses likuifikasi $\mathrm{pH}$ yang optimal 6 sedangkan pada sakarifikasi $\mathrm{pH}$ yang optimal adalah 4,5 [36].

e. Suhu

Aktifitas enzim meningkat seiring dengan bertambahnya suhu sampai mencapai aktifitas optimal, setelah mencapai aktifitas optimal penambahan suhu dapat menyebabkan turunnya aktifitas enzim tersebut. 
Temperatur untuk likuifikasi adalah $105{ }^{\circ} \mathrm{C}$ kemudian transisi dari proses likuifikasi ke proses sakarifikasi pada suhu $95{ }^{\circ} \mathrm{C}$ dan proses sakarifikasi pada suhu $60{ }^{\circ} \mathrm{C}[37]$.

\section{Tahapan Hidrolisis Enimatik}

a. Gelatinisasi

Gelatinisasi merupakan proses yang bertujuan untuk memecah pati yang berbentuk granular menjadi suspensi yang kental. Pada tahap ini granular pati dibuat bengkak akibat adanya peningkatan volume oleh air dan tidak dapat kembali lagi ke kondisi awal. Perubahan ini disebut gelatinisasi. Suhu pada saat granular tersebut pecah disebut suhu gelatinisasi. Gelatinisasi dapat terjadi dengan adanya panas [38].

b. Likuifikasi

Tahap likuifikasi adalah proses hidrolisis pati menjadi dekstrin oleh enzim pada suhu di atas suhu gelatinisasi dan pH optimal. Proses likuifikasi berakhir ditandai dengan larutan menjadi encer. Proses gelatinisasi merupakan bagian dari likuifikasi. Reaksi likuifikasi disajikan pada Persamaan 1 [38].

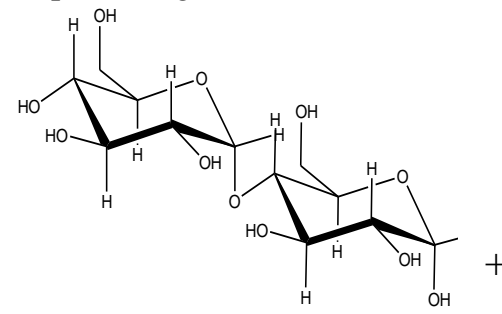

amilosa

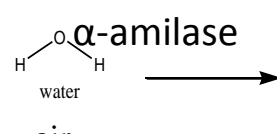

air

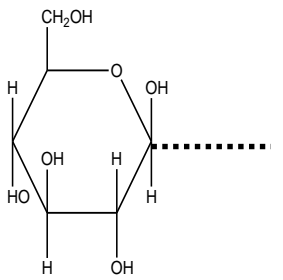

maltodextrin

c. Sakarifikasi

Tahap sakarifikasi merupakan tahap pemecahan gula kompleks hasil dari tahap likuifikasi menjadi glukosa dengan adanya enzimglucosidase. Pada tahap ini dekstrin diubah menjadi glukosa. Reaksi sakarifikasi digambarkan pada Persamaan 2 [38].

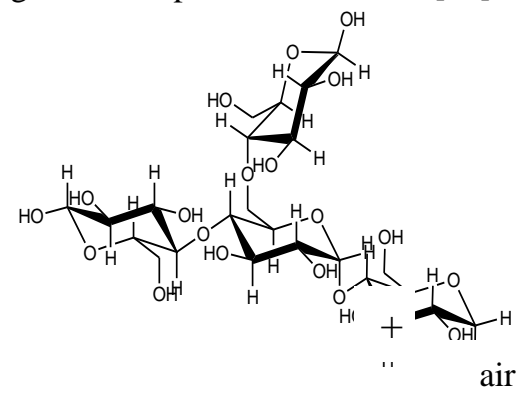

amilopektin
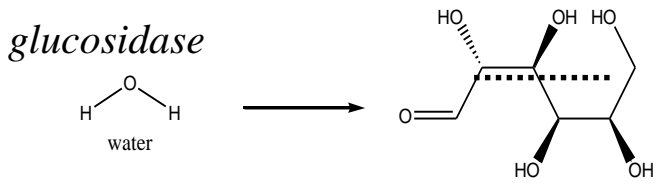

glukosa

\section{d. Pemurnian}

Untuk tahap terakhir adalah pemurnian glukosa bisa dilakukan dengan absorpsi arang aktif atau dengan evaporasi. Pemurnian glukosa dan fruktosa yang terbentuk dalam skala industri menggunakan ion exchange dengan adsorben berupa zeolite [39]. Hidrolisis hidrotermal dapat dilakukan untuk mengurangi inhibitor sehingga akan menambah yield glukosa [40].

\section{Enzim}

Enzim merupakan protein yang berfungsi sebagai katalisator reaksi biologi atau sering disebut dengan biokatalisator. Enzim dapat mempercepat suatu reaksi hingga $10^{12}$ sampai $10^{20}$ kali. Umumnya reaksi kimia dalam sel yang hidup terjadi sangat lambat jika tidak ada katalis seperti enzim. Enzim dapat menurunkan energi aktivasi tersebut sehingga reaksi dapat berlangsung dengan cepat. Energi aktivasi adalah energi yang harus diberikan terhadap bahan yang stabil untuk memulai suatu reaksi. Sebelum molekul-molekul tersebut bereaksi harus melalui suatu konfigurasi aktif. Pada keadaan ini molekul tersebut mempunyai energi yang lebih besar daripada molekul dalam keadaan normal. Energi aktivasi yang dibutuhkan setiap enzim berbedabeda tergantung dari jenis enzimnya [28]. Reaksi antara enzim dan substrat disajikan pada Persamaan 3 [41].

$\mathrm{E}+\mathrm{S} \Leftrightarrow \mathrm{ES} \rightarrow \mathrm{E}+\mathrm{P}$ 
$\mathrm{E}$ adalah enzim, $\mathrm{S}$ adalah substrat, $\mathrm{ES}$ adalah kompleks yang terbentuk dan $\mathrm{P}$ adalah produk yang dihasilkan. Sebelum menjadi produk suatu reaksi terlebih dahulu akan terbentuk kompleks antara katalisator dengan substrat, yang biasa disebut kompleks enzim-substrat. Kompleks enzim-substrat ini terjadi akibat enzim pada permukaannya mempunyai bagian yang reaktif sehingga dapat mengikat substrat. Setelah kompleks terbentuk, maka ikatan di dalam substrat akan pecah menjadi beberapa bentuk hasil reaksi. Kemudian enzim dilepaskan kembali untuk selanjutnya menangkap substrat yang baru dan mengulangi seperti semula [41].

Kelebihan enzim dibandingkan katalis lain adalah: dapat meningkatkan produk, bekerja pada $\mathrm{pH}$ netral dan pada suhu rendah, bersifat selektif pada substrat tertentu [28]. Enzim dapat mempercepat reaksi namun enzim tidak dapat mengubah keadaan normal dari kesetimbangan kimia, atau dengan kata lain enzim hanya mempercepat reaksi pembentukan produk tetapi tidak dapat mengubah yield dari produk [42].

Ada beberapa kondisi yang dapat mempengaruhi aktifitas enzim, diantaranya:

a. Pengaruh suhu

Kecepatan katalisis oleh enzim akan naik apabila suhu dinaikkan.Namun jika enzim sudah mencapai keadaan optimalnya suhu sudah tidak berpengaruh lagi. Penambahan suhu yang lebih tinggi pada keadaan enzim yang sudah optimal akan menyebabkan penurunan aktifitas enzim, bahkan bisa menyebabkan kerusakan pada enzim [31].

b. Pengaruh $\mathrm{pH}$

Enzim mempunyai aktifitas yang maksimum pada kisaran $\mathrm{pH}$ tertentu atau biasa disebut $\mathrm{pH}$ optimal. Enzim merupakan suatu protein, adanya keadaan yang terlalu asam akan menyebabkan denaturasi protein atau rusaknya protein. Umumnya kisaran $\mathrm{pH}$ optimal dari enzim adalah 4,5-8. $\mathrm{pH}$ optimal enzim tergantung pada substratnya [34].

c. Pengaruh konsentrasi enzim

Kecepatan reaksi enzimatik berbanding lurus dengan konsentrasi enzim. Semakin tinggi konsentrasi enzim, semakin meningkat juga kecepatan reaksinya. Namun saat kecepatan reaksi sudah mencapai keadaan konstan, penambahan konsentrasi enzim tidak mempengaruhi kecepatan reaksi [43].

d. Pengaruh konsentrasi substrat

Kecepatan reaksi akan meningkat seiring bertambahnya konsentrasi substrat. Peningkatan kecepatan reaksi akan semakin kecil sampai mencapai titik dimana penambahan substrat sudah tidak mempengaruhi kecepatan reaksi enzim lagi. Hal ini disebabkan semua molekul enzim sudah membentuk ikatan kompleks dengan substrat [32].

e. Pengaruh aktivator dan inhibitor

Aktivator adalah senyawa atau ion yang dapat meningkatkan kecepatan reaksi enzimatik dari enzim. Komponen kimia tersebut dapat disebut kofaktor. Beberapa ion yang termasuk kofaktor antara lain $\mathrm{Zn}, \mathrm{Fe}$, $\mathrm{Ca}, \mathrm{Mn}, \mathrm{Cu}$, dan $\mathrm{Mg}$. Kofaktor dapat pula berupa molekul organik kompleks yang disebut koenzim. Ikatan yang dibentuk dengan koenzim biasanya lemah, jika ada ikatan kuat disebut gugus prostetis. Kerja enzim dipengaruhi juga dengan adanya inhibitor atau penghambat. Inhibitor merupakan senyawa atau ion yang dapat menghambat aktifitas enzim. Sifat penghambatan dibagi menjadi tiga [28]:

1. Penghambatan non-spesifik

Enzim yang merupakan protein akan mengalami denaturasi dalam keadaan asam. Denaturasi selain disebabkan adanya kadar asam yang tinggi juga dapat disebabkan oleh timbulnya endapan dari asam trikloroasetat.

2. Penghambatan kompetitif

Penghambatan kompetitif terjadi apabila inhibitor dan substrat saling memperebutkan sisi aktif dari enzim.

3. Penghambatan non-kompetitif

Penghambatan ini terjadi jika inhibitor bergabung pada sisi aktif enzim. Aktifitas enzim akan terganggu karena sisi aktif ini penting bagi aktifitas enzim.

\section{Jenis-Jenis Enzim}

Enzim mempunyai sifat yang khas yaitu hanya mampu bekerja pada substrat yang cocok. Berikut ini adalah jenis-jenis enzim yang digunakan pada pembuatan glukosa dan fruktosa secara enzimatik:

\section{Enzim $\alpha$-amilase}

Amilase adalah suatu enzim yang mampu memecah ikatan glukosidik yang terdapat pada pati. Amilase dapat diperoleh dari bermacam-macam sumber.Enzim $\alpha$-amilase adalah amilase yang dapat menghidrolisis 
ikatan $\alpha-1,4$ glukosidik pada polimer pati secara internal. Mekanisme kerja $\alpha$-amilase dibagi menjadi dua tahap yaitu tahap degradasi amilosa dan pembentukan glukosa dan maltosa. Tahap pertama degradasi amilosa menjadi maltosa dan maltotriosa yang terjadi secara acak. Degradasi tersebut terjadi sangat cepat dan diikuti dengan penurunan viskositas. Tahap kedua adalah pembentukan glukosa dan maltosa sebagai produk, tidak acak dan reaksi terjadi sangat lambat. Kerja enzim $\alpha$-amilase pada molekul amilosa dapat berlangsung cepat. Hal ini disebabkan pada rantai lurus lebih mudah terdegradasi daripada rantai bercabang.Enzima-amilase didapatkan dari malt, ludah manusia, Aspergillus oryzae, Bacillus subtilis, Bacillus lichenformis [43].

2. Enzim $\beta$-amilase

Enzim $\beta$-amilase ( $\beta$-1,4 glukanmaltohidrolase) dapat diisolasi dari kecambah barley, ubi jalar dan kacang kedelai. Enzim $\beta$-amilase berperan dalam memecah ikatan glukosida $\beta-1,4$ pada pati dan glikogen dengan mengembalikan konfigurasi karbon anomeri $\left(C_{1}\right)$ glukosa dari $\alpha$ menjadi $\beta$, maka enzim tersebut disebut enzim $\beta$-amilase. Cara hidrolisis oleh enzim $\beta$-amilase adalah dengan memotong 2 unit glukosa dan secara bertahap pemotongan dari ujung rantai gula yang bukan pereduksi, disebut eksamilase. Enzim $\beta$-amilase aktif pada $\mathrm{pH}$ 5-6 [43].

3. Enzim glucosidase

Enzim glucosidase atauglukoamilasediperoleh dari Aspergillus dan Rhizopus. Enzim tersebut digunakan utuk memecah ikatan $\alpha-1,6$ seperti halnya ikatan $\alpha-1,4$ dalam likuifikasi pada pati yang dicairkan atau gelatin. Produk yang terbentuk adalah glukosa dengan memecah substrat pati dari ujung non-pereduksi. Dextrose equivalent yang dihasilkan mencapai 95-98\% dengan konversi mencapai 93-95\%. Kondisi operasi enzim glukoamilase adalah suhu $40-60{ }^{\circ} \mathrm{C}, \mathrm{pH} 4,5$ dan waktu reaksi yang diperlukan sekitar 48-96 jam [32].

\section{Enzim isomerase}

Enzim isomerase merupakan enzim yang digunakan sebagai katalis reaksi perubahan konfigurasi molekul dengan cara pengaturan kembali atom substrat, sehingga menghasilkan molekul baru yang merupakan isomer dari substrat dengan perubahan isomer misalnya merubah aldosa menjadi ketosa [42].

\section{Jenis-Jenis Gula dari Pati Ubi Kayu}

a. Maltodextrins

Maltodextrins merupakan polimer sakarida yang terdiri dari D-glukosil yang mempunyai ikatan utama $\alpha$ 1,4 dan mempunyai DE (Dextrose Equivalen) kurang dari 20\% sehingga maltodextrin tidak dikenal sebagai pemanis. Maltodextrin didapatkan dari pati kentang. Pada tahun 1992, sudah lebih dari 328 juta pound maltodextrin dan glukosa diproduksi di Amerika Serikat dari berbagai jenis pati. Maltodextrin diproduksi tidak hanya dengan hidrolisis asam tetapi juga dengan hidrolisis enzimatik. Maltodextrin yang diproduksi dengan enzimatik konversinya lebih tinggi. Namun kemampuan bercampur kembali dengan komponen yang tidak larut dengan air lambat,sehingga harus ada perlakuan terlebih dahulu. Perlakuan formasi menyebabkan retrodegradasi dapat timbul oleh enzim $\alpha$-amilase. Enzim tersebut meninggalkan bagian terbesar dari fragmen cabang, sehingga mengurangi kemampuan fragmen untuk bercampur kembali [44].

Pada proses katalisis enzim, slurry (30\% sampai 40\% DS) dengan temperatur $80-90{ }^{\circ} \mathrm{C}$ diperlakukan dengan panas dengan penambahan bakteri $\alpha$-amilase untuk proses likuifikasi. Enzim $\alpha$-amilase dari $B$. licheniformis atau B. stearothermophilus dapat tahan sampai temperatur $90-105^{\circ} \mathrm{C}$ selama 30 menit ketika mencapai keadaan stabil dengan ion kalsium. Waktu 30 menit cukup untuk proses pemisahan ikatan $\alpha-1,4$ dan membentuk maltodextrin. Reaksi proses fragmentasi mendapatkan maltodextrin dengan DE 12-15 [44].

Sumber utama pati untuk memproduksi maltodextrin adalah jagung, kentang, dan beras tetapi bisa juga diperoleh dari berbagai bahan lain seperti tapioka, gandum, sorghum, dan lain-lain. Kandungan dextrose equivalent pada maltodextrin tergantung pada komposisi dan sifat kimia fisika dari pati yang digunakan. Berbagai penelitian telah dilakukan untuk menentukan kebutuhan waktu pada hidrolisis enzimatik pada reaktor batch. Pada penelitian tersebut, tidak ada perbedaan stastistik yang signifikan pada kandungan kelembaban dan karbohidrat, tetapi terdapat perbedaan pada kandungan komponen lain seperti abu, protein, lemak dan amilosa. Sehingga komposisi kimia dan lemak, protein, amilosa dan fosfor mempunyai pengaruh besar pada kesuksesan pada hidrolisis enzimatik [23].

\section{b. Glukosa}

Glukosa $\left(\mathrm{C}_{6} \mathrm{H}_{12} \mathrm{O}_{6}\right)$ merupakan monosakarida yang banyak ditemukan di alam. Sirup glukosa adalah cairan jernih dan kental yang mempunyai komponen utama adalah glukosa. Sirup glukosa banyak dimanfaatkan pada industri pangan dan obat-obatan. Mutu dari sirup glukosa ditentukan dari warna sirup, kadar air dan tingkat konversi pati yang dihitung sebagai ekuivalen dekstrosa (DE). Nilai ekuivalen dextrosa (DE) pada sirup glukosa yang tinggi bisa diperoleh dengan optimasi proses likufikasi dan sakarifikasi. Untuk kadar padatan kering dan warna pada sirup glukosa agar memenuhi standar (SNI 0418-81 tahun 2001) 
didapatkan dengan cara evaporasi. Evaporasi berlangsung pada keadaan non-vakum, proses ini dapat menyebabkan warna sirup glukosa menjadi kecoklatan. Syarat mutu sirup glukosa disajikan pada Tabel 2 dan struktur kimia glukosa disajikan pada Gambar 2 [34].

Tabel 2. Syarat Mutu Sirup Glukosa

\begin{tabular}{clc}
\hline No. & \multicolumn{1}{c}{ Komponen } & Spesifikasi \\
\hline $\mathbf{1}$ & Air & Max 20\% \\
$\mathbf{2}$ & Abu (dasar reduksi) & Max 1\% \\
$\mathbf{3}$ & Gula reduksi sebagai D-Glukosa & Min 30\% \\
$\mathbf{4}$ & Pati & Tidak nyata \\
$\mathbf{5}$ & Logam berbahaya $(\mathrm{Pb}, \mathrm{CN}, \mathrm{Zn})$ & Negatif \\
$\mathbf{6}$ & Pemanis buatan & Negatif \\
\hline
\end{tabular}

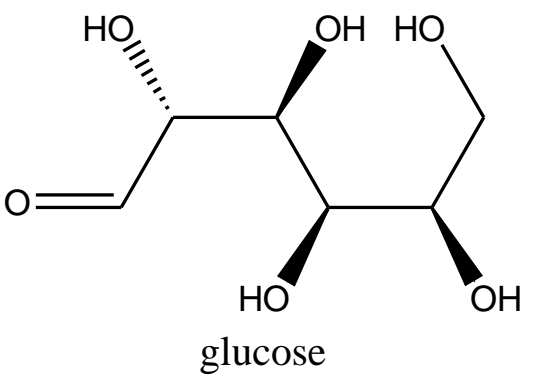

Gambar 2. Struktur Kimia Glukosa

Polisakarida terdiri dari glukosa, oligomernya (polimer rantai pendek) dan komponen dari sirup yang mempunyai berat molekul dari 180 hingga mencapai 3000. Masing-masing sirup terdiri dari bagian-bagian yang bervariasi tergantung pada komponen penyusunnya yang mempunyai sifat yang berbeda. Ciri utama dari sifat glukosa adalah pada dextrose equivalent (DE) yaitu ukuran total perbandingan total gula reduksi dalam sirup dibanding dengan dextrosa yang dihitung pada basis kering. Selain DE ciri yang menentukan lainnya adalah komposisi karbohidratnya. Sirup glukosa yang mempunyai DE yang sama tetapi cara produksinya berbeda dapat menghasilkan profil dan sifat hidrolisis yang berbeda [27].

Pemecahan gula pada suhu rendah hanya akan menghasilkan zat-zat dengan warna gelap yang akan menurunkan mutu gula. Konversi glukosa dengan enzim dapat menghasilkan glukosa dengan kadar dekstrosa mencapai 95\%. Enzim sangat berpengaruh terhadap kadar dekstrosa yang dihasilkan, apabila enzim yang digunakan tidak murni, dektrosa akan berkurang karena adanya trans-glukosa. Waktu konversi yang terlalu lama dan dosis enzim yang terlalu tinggi menyebabkan terbentuknya maltosa [29].

Kelarutan dekstrosa sama dengan kelarutan sukrosa pada suhu $60{ }^{0} \mathrm{C}$. Pada suhu dibawah itu kelarutan sukrosa lebih tinggi dari kelarutan dekstrosa, sebaliknya pada suhu diatasnya kelarutan dekstrosa lebih tinggi. Suhu transisi untuk dekstrosa adalah $50{ }^{\circ} \mathrm{C}$, pada suhu di bawah suhu tersebut glukosa dapat membentuk fasa padat. Dektrosa tidak mudah mengkristal. Larutan dekstrosa mencapai kejenuhan $75 \%$ dan pada suhu tinggi inti kristal glukosa dapat terbentuk [29].

c. Fruktosa

Fruktosa adalah monosakarida yang mempunyai rumus kimia $\mathrm{C}_{6} \mathrm{H}_{12} \mathrm{O}_{6}$ sama dengan glukosa. Perbedaan antara glukosa dan fruktosa adalah pada putaran polarisasi jika glukosa sifat memutar polarisasi ke arah kanan (+). Fruktosa sifat putarnya kebalikannya yaitu ke arah kiri atau (-). Fruktosa juga tidak dapat dipecah lagi menjadi rumus yang lebih sederhana [44]. Struktur fruktosa disajikan pada Gambar 3 berikut ini.

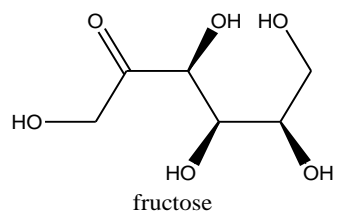

Gambar 3. Struktur Fruktosa

Fruktosa merupakan pemanis yang berasal dari buah-buahan yang sering digunakan dalam industri makanan dan minuman. Selain itu fruktosa khususnya ester fruktosa juga digunakan dalam industri kosmetik dan farmasi, karena fruktosa memiliki stabilitas emulsi antara minyak dan air. Kekuatan penyabunan awaldan 
nilai tegangan permukaan pada ester fruktosa yang lebih tinggi dari sukrosa ester [44]. Fruktosa dapat dibuat dari isomerisasi glukosa menggunakan enzim isomerase [14]. Pada tahun 1970-2005 kebutuhan fruktosa sebagai High Fructose Corn Syrup (HFCS) di Amerika meningkat sebagai pengganti gula biasa. Peningkatan konsumsi perkapita HFCS mencapai lebih dari 40 pound rata-rata sampai tahun 2009 [38].

\section{Kesimpulan}

Dari studi literatur yang telah dilakukan diperoleh kesimpulan bahwa tahapan hidrolisis enzimatik pada pati ubi kayu ada tiga yaitu gelatinisasi, liuifikasi dan sakarifikasi. Faktor-faktor yang mempengaruhi hidrolisis enzimatik pada pati ubi kayu adalah konsentrasi enzim, waktu hidrolisis, pH, suhu. Enzim yang digunakan untuk hidrolisis enzimatik pada umumnya ada dua. Enzim alpha amilase untuk tahap liquifikasi dan enzim glukosidase untuk tahap sakarifikasi. Gula produk dari hidrolisis enimatik antara lain maltodextrin, glukosa dan fruktosa. Guladari pati singkong ini memiliki kualitas yang hampir sama dengan gula tebu sehingga bisa digunakan untuk mengurangi impor gula dari luar negeri.

\section{Daftar Pustaka}

[1] -, 2016. Ekspor Impor. www.BPS/eksporimpor.go.id, 19 Juli 2016.

[2] Aderibigbe,A.F., Anozie,A.N., Adejumo,L.A. and R.U. Owolabi, 2012. Optimization of Cassava Starch Hydrolysis by Sorghum Malt. New Clues in Sciences, 2 (3) ,pp.50-58.

[3] Moretti, M.M.S., Martins, D.A.B., Nunes, C.C.C., Villena, M.A., Perrone, O.M., Silva, R., Boscolo, M., Gomes, E., 2014. Pretreatment of Sugarcane Bagasse with Microwaves Irradiation and Its Effects on The Structure and on Enzymatic Hydrolysis. Applied Energy, 122, pp. 189-195.

[4] Ulibarri, R.L. and Hall, G.M., 1997. Saccharification of Cassava Flour Starch in A Hollow-Fiber Membrane Reactor. Elsevier, 0229(97), pp.398-404.

[5] Johnson, R. and Padmaja, G., 2013. Comparative Studies on the Production of Glucose and High Fructose Syrup from Tuber Starches. International Research Journal of Biological Sciences, 2(10), pp.68-75.

[6] Jati, P.W., 2006. Pengaruh Waktu Hidrolisis dan Konsentrasi HCl Terhadap Nilai Dextrose Equivalent (DE) dan Karakterisasi Mutu Pati Termodifikasi dari Pati Tapioka Dengan Metode Hidrolisis Asam, Skripsi, Institut Pertanian Bogor, Bogor, Indonesia.

[7] Putri, L. S. E. dan Sukandar, D., 2008, Konversi Pati Gayong (Canna edulis Ker.) Menjadi Bioetanol melalui Hidrolisis Asam dan Fermentasi. Biodiversitas, 9(2), pp. 112-116.

[8] Cecil, J.E., 1995. The Use Of Cassava Starch In The Artisanal Production Of Maltose, Food And Agricultural Industries Service”. Agricultural Services Division. FAO. Rome, Italy. pp. 500-504.

[9] Damajanti, N., Mulyadi, A.H. dan Listianingrum, 2012. Bioplastik Poly Lactic Acid (PLA) dari Kulit Singkong dengan Variasi Jenis Bakteri Lactobacillus. In Prosiding Seminar Nasional Teknoin.

[10] Saelim, K., Dissara, Y., Kittikum, A.H., 2007. Saccarification of Cassava Starch by Saccharomycopsis fibuligera YCYI Isolated from Loong-Pang (rice cake starter). Songklanakarin Journal of Science and Technology. 30. pp. 65-71.

[11] Putri, W.D.R., Marseno, D.W. dan Cahyanto, M.N., 2012. Role of Lactic Acid Bacteria on Structural and Physicochemical Properties of Sour Cassava Starch. APCBEE Procedia, 2, pp.104-109.

[12] Souza, F.H.M., Inocentes, R.F., Ward, R.J., Jorge, J.A., Furriel, R.PM., 2013. Glucose and Xylose Stimulation of a $\beta$-glucosidase from The Thermophilic Fungus Humicola. Journal of Molecular Catalysis B : Enzymatic, 94, 119-128.

[13] Yoonan, K. and Kongkiattikajorn, J., 2004, A Study of Optimal Conditions for Reducing Sugars Producton from Cassava Peels by Diluted Acid and Enzymes. Kasetsart Journal (Natural Science) 38, pp. 29- 35.

[14] Baskar, G., Muthukumaran, C., Renganathan, S., 2008, Optimization of Enzymatic Hydrolysis of Manihot Esculenta Root Starch by Immobilize $\alpha$-Amylase Using Response Surface Methodology. International Jurnal of Natural Sciences and Engineering, 1(3), pp. 156-160.

[15] Chamsart, S., Sawangwon, C., Tungkao, S., and Waiprib, Y., 2006, Enzymatic Hydrolysis of Cassava Starch in a Stirred Tank Lysis Reactor. In Proceeding of the 15th Thailand Chemical Engineering and Applied Chemistry, Chonburi, 28-29. 
[16] Wojciechowski, A.L., Nistsche, S., Pandey, A. and Socco, C. R., 2002. Acid and Enzymatic Hydrolysis to Recover Reducing Sugars from Cassava Bagasse : An Economic Study. Brazilian Archives of Biology and Technology. 45(3), pp.393-400.

[17] Singh, V., Tiwari, A., Kumari, P., Tiwari, S., 2006. Microwave-Promoted Hydrolysis of Plant Seed Gums on Alumina Support. Carbohydrate Research, 341, pp. 2270-2274.

[18] Miraglia, S., 2009. Alpha Amylase and High Fructose Corn Syrup [artikel online].

[19] Zulaidah, A., 2011. Modifikasi Ubi Kayu Secara Biologi Menggunakan Starter Bimo-CF Menjadi Tepung Termodifikasi Pengganti Gandum [TESIS]. Universitas Diponegoro Semarang.

[20] Widiasa, I.N., Susanto, H., 2009. Ultrafiltration Fouling of Amylose Solution : Behavior , Characterization and Mechanism. Journal of Food Engineering, 95(3), pp.423-431.

[21] Ramachandran, V., Pujari, N., Matey, T., Kulkarni, S. and Rice, A., 2013. Enzymatic Hydrolysis for Glucose-A Review. International Journal of Science, Engineering and Technology Research, 2(10), pp.1937-1942.

[22] Gomand, S. V.,Lamberts, L., Derde, L.J., Goesaert, H., Vandeputte, G.E., Goderis, B., Visser, R.G.F. and Delcour, J A 2010. Structural Properties and Gelatinisation Characteristics of Potato and Cassava Starches and Mutants Thereof. Food hydrocolloids, 24(4), pp.307-317.

[23] Charonenkul, N., Uttapap, D., Pathipanawat, W., Takeda, Y., 2011. Physicochemical Characteristic of Starches and Flour from Cassava Varieties Having Different Cooked Root Textures. LWT Food Science and Technology, 44, pp. 1774-1781.

[24] Zhu, F., 2014. Review : Composition, Structure, Physicochemical Properties and Modifications of Cassava Starch. Carbohydrate Polymers, xxx, pp. Xxx-Xxx.

[25] Celebi, İ., 2006. Color Formation in Wheat Starch Based Glucose Syrups and Use of Activated Carbons for Sugar Decolorization. The Graduate School Of Natural And Applied Sciences Of Middle East Technical University.

[26] Rochmawatin, N., 2010. Pengaruh Konsentrasi Enzim dan Lama Sakarifikasi pada Hidrolisis Enzimatis terhadap Produksi Sirup Glukosa dari Pati Ubi Kayu (Manihot Esculenta)[SKRIPSI]. Universitas Islam Negeri (UIN) Maulana Malik Ibrahim Malang.

[27] Kunamneni, A. and Singh, S., 2005. Response Surface Optimization of Enzymatic Hydrolysis of Maize Starch for Higher Glucose Production., pp.14-16.

[28] Dincbas, S. and Demirkan, E., 2010. Comparison of Hydrolysis Abilities onto Soluble and Commercial Raw Starches of Immobilized and Free B.amyloliquefaciens $\alpha$-Amylase. Journal Biol.Environ.Sci, 4(11), pp.87-95.

[29] Ayoola, A.A., Adeeyo, O.A.,Efeovbokhan, V.C. and Ajileye, O., 2012. A Comparative Study on Glucose Production from Sorghum Bicolor and Manihot Esculenta Species in Nigeria. International Journal of Science and Technology, 2(6), pp.353-357.

[30] Scholz, M.J., Riley, M.R. and Cuello, J.L., 2012. Acid Hydrolysis and Fermentation of Microalgal Starches to Ethanol by The Yeast Saccharomyces cerevisiae. Biomass and Bioenergy, 48, pp.59-65.

[31] Triyono, A., 2008. Karakteristik Gula Glukosa dari Hasil Hidrolisa Pati Ubi Jalar ( Ipomoea Batatas , L .) dalam Upaya Pemanfaatan Pati Umbi - Umbian. In Seminar Nasional Teknoin Bidang Teknik Kimia dan Tekstil., pp. 7-10.

[32] Omemu, A.M., Akpan, I., Bankole, M.O., Tenida, O.D., 2005. Hydrolisis of Raw Tuber Starches by Amylase of Aspergillus niger AMO7 Isolated from The Soil. African Journal of Biotechnology, 4 (1), pp. $19-25$

[33] Olasimbo, A.,Ayoola, A., Adeeyo, O. and Efeovbokhan, V., 2013. Optimum Hydrolysis Conditions of Cassava Starch for Glucose Production. International Journal of Advanced Research in IT and Engineering, 2(1), pp.93-101.

[34] Rahmayanti, D., 2010. Pemodelan dan Optimasi Hidrolisa Pati Menjadi Glukosa dengan Metode Artificial Neural Network-Genetic Algorithm (ANN-GA) [SKRIPSI]. Universitas Diponegoro Semarang.

[35] Kuhn, R.C., Mazutti, M.A., Filho, F.M., 2012. Kinetic and Mass Transfer Effect for Adsorption of Glucose, Fructose, Sucrose and Fructooligosaccarides into X-zeolite. LWT Food Science and Technology, 48, pp. 127-133. 
[36] Orozco, R.L. Redwood, M.D., Leeke, G.A., Bahari, A., Santos, R.C.D. and Macaskie, L.E., 2012. Hydrothermal Hydrolysis of Starch with $\mathrm{CO}_{2}$ and Detoxification of The Hydrolysates with Activated Carbon for Biohydrogen Fermentation . International Journal Hydrogen Energy, (1), pp.1-17.

[37] Garneau, S., Tsodikova, Shkel, I.A., Tsodikov, O. A., 2009. Exact and User Friendly Kinetic Analysis of Two Step Rapid Equilibrium Michaelis-Menten Mechanism. Analytical Biochemistry, 387, pp. 276279.

[38] Risnoyatiningsih, S., 2011. Hydrolysis of Starch Saccharides from Sweet Potatoes Using Enzyme. Jurnal Teknik Kimia, 5(4), pp.417-424.

[39] Saraswati, Rosidah, I. dan Hapsari, D.Y., 2004. Pembuatan Glukosa Secara Enzimatik dari Bahan Baku Pati Sagu. Jurnal Teknik Kimia Indonesia, 3, pp.56-63.

[40] El-fallal, A., Dobara, M.A., El-sayed, A. and Omar, N., 2012. Starch and Microbial $\alpha$-Amylases : From Concepts to Biotechnological Applications. Intech, pp.459-488.

[41] Hobbs, L., 2009. Sweeteners from Starch : Production, Properties and Uses Third., Elsevier Inc.

[42] Indah, S., 2009. Pra Rancangan Pabrik Pembuatan Glukosa Dari Pati Jagung dengan Proses Hidrolisa Dengan Kapasitas 12000 Ton/Tahun[SKRIPSI]. Universitas Sumatera Utara Medan.

[43] Nguyen, H.M., Ha, S.H., Koo, Y.M., 2008. Optimization of Lipase-Catalyzed Fructose Palmitate Synthesis in Ionic Liquid. Jurnal of Biotechnology, 136s, pp. s356-s401.

[44] Curcio, S.Iorio, G.,Ricca, E. and Calabro, V., 2009. Fructose Production by Chicory Inulin Enzymatic Hydrolysis : A Kinetic Study and Reaction Mechanism.Process Biochemistry, 44, pp.466-470. 